\title{
Voices from the Working Lives Project: The Push-pull of Work and Care
}

\author{
Heather Fehring $^{1}$ \& Katherine Herring ${ }^{1}$ \\ ${ }^{1}$ School of Education, RMIT University, Australia \\ Correspondence: Heather Fehring, School of Education, RMIT University, Bundoora West, 3083, Victoria, \\ Australia. Tel: 61-399-257-840. E-mail: heather.fehring@rmit.edu.au
}

Received: July 18, 2012

Accepted: July 31, 2012 Online Published: October 15, 2012

doi:10.5539/ies.v5n6p204

URL: http://dx.doi.org/10.5539/ies.v5n6p204

\begin{abstract}
A recent policy direction in many OECD countries has been to increase workforce participation for women of childbearing age; a policy direction which seemingly runs counter to a need for improved work-life balance for women themselves. This article explores the impact of this somewhat contradictory 'push-pull' of policy by examining some difficulties of workforce participation, transition and re-entry articulated by female case study participants from an Australian Research Council funded study, which examined the career decision-making of contemporary Australian workers. Against a backdrop of the larger study, this article features detail from interviews with skilled women workers on their return from maternity leave, particularly addressing their difficult transitions between work and care and their varying responses to workplace marginalisation. In light of policy initiatives aimed to boost workforce participation, this article aims to contribute to raising the profile of issues surrounding the cost of parenting to contemporary women.
\end{abstract}

Keywords: Australia, gender, life course transitions, work-life balance, workforce participation

\section{Introduction}

Many Organisation for Economic Co-operation and Development (OECD) countries, including Australia, are facing an ongoing shortage of qualified young people in a number of skilled occupations (Richardson, 2007). The current era is also characterised by rapid technological change, an ageing workforce, and transformations of traditional patterns of work (Skills Australia., 2009, 2010, 2011). An important policy initiative, particularly in response to an ageing workforce, has been to increase the workforce participation of women who are of childbearing age in many countries, including Australia (Jaumotte, 2003/02; Schmid, 2006; Skills Australia., 2010). However, this direction in policy seemingly runs counter to a need for improved work-life balance for women themselves (Jamieson \& Morton, 2005; Jeanes, Knights, \& Martin, 2011; Yerkes, Standing, Wattis, \& Wain, 2010).

In relation to the Australian political landscape, this 'push-pull' of policy has been identified by Walter (2005) and Hill (2006) and has even been called “contradictory" (in relation to women's partnered status) (Andrew, 2008, p. 374). It has been argued that past Australian governments have expressed ambivalence about whether to "support women as home-based carers, wage earners, or both" (Brennan, 2007, p. 31). Tensions between incentives to care and work in Australia have been the focus of considerable research throughout the last decade (Burgess \& Strachan, 2005; Craig, Mullan, \& Blaxland, 2010; Pocock, 2003). More recently, analysts have identified as regressive the policy settings that were in place from the late 1990s to 2006 (Craig, et al., 2010; Maddison \& Partridge, 2007).

This article explores the impact of this somewhat contradictory 'push-pull' of policy, by examining some difficulties faced in workforce participation, transition and re-entry surrounding maternity leave, articulated by female case study participants from a larger study which examined the career decision-making of contemporary Australian workers. The data presented in this article is drawn from the Working Lives project (Fehring, Malley, \& Robinson, 2008) which was an Australian Research Council (ARC) funded Linkage Project undertaken between 2006 and 2009. It involved a multidisciplinary research team from RMIT University, NCVER (National Centre for Vocational Education and Research), DEECD (Department of Education and Early Childhood Department, Victoria) and The Skilled Group. The initial investigation was a small-scale exploratory study which mapped and compared the work, benefit and skill (WBS) trajectories of trade and higher education completers who graduated from RMIT University in Australia, a dual-sector educational institution, between 1994 and 1996. The 
fundamental aim of the research was to explore the reasons why workers in their first ten years of post-qualification working life made certain career changes over others. For example, why they did or did not move jobs, change careers, seek promotion, or step out of the workforce, especially at a time of skill shortage and rapid technological and sociological change (Fehring, Malley, \& Robinson, 2008).

The three stages of data gathering from the study yielded a composite portrait of working lives in contemporary Australia; with Stage 3, in particular, taking the form of a series of case study interviews. Although gender was not an explicit variable in the Working Lives project, a number of pertinent issues emerged from the data which related specifically to the working lives of women. These issues form the basis of the current article. The term gender is used generically to refer to both male and female constructs. However, we acknowledge the contested nature in interdisciplinary literature of the use of this term over the last 40 years (Acker, 1990; Ramazanoglu \& Holland, 2002; Scott, 1986). Using the voices of case study participants, the research documents difficult transitions between work and care, and accompanying feelings of frustration owing to entrenched gender inequities in the workplace (Fehring, Malley, \& Herring, 2009). The interview data specifically raises the 'after the baby' experience for these women (Baird \& Charlesworth, 2007). Before addressing those issues, a brief overview of the broader project is provided.

\section{Background Context}

The design of this research project was shaped by two developments in the literature on skill and work, both relevant to a climate of skill shortage. The first is the critical discourse surrounding returns to investment in education (Blundell, Dearden, \& Sianesi, 2004; McIntosh, 2002). The second is the development of longitudinal techniques to investigate occupational progressions throughout working life (DEECD, April, 2010; Mayer, 2000; Ruspini, 1999; Ziguras, 2006). Perceptions of relative job worth have traditionally been influenced by large, cross-sectional, point-in-time surveys that compare average occupational wage levels and private returns to investment in education and training. Such approaches tend to mask the dynamic nature of lived experience: of career pathways and life courses. They promulgate a static perception of the individual's place, or position in the labour market, and offer little insight into the motivations that drive job and career change (DEECD, April, 2010).

A novel direction in rate of return studies has been the concept of benefit which encompasses variables other than simple earnings. Such a direction draws on an emerging body of research which suggests that not everyone has the opportunity to enact occupational preferences which would maximise earnings, and that many prefer benefits such as shorter working hours and location to earnings per se, as they attempt to strike an approripariate work-life balance (Fehring, et al., 2008; Fevre, Rees, \& Gorard, 1999). In order to address this kind of complex (seemingly economically irrational) fluctuation in labour markets, various longitudinal studies of skills acquisition and occupational change have been proposed and undertaken (Bartel, 2000; McIntosh, 2005). The evolution of life course theory, as explained by Elder (1998), is a direct result of the growth and sophistication of longitudinal studies. Such a methodology permits nuanced data gathering and interpretation, sensitive to issues of "time, process, and context" as these apply to both the individual and to social structures (Elder, 1998, p. 5).

Investigating labour market dynamics using a life course approach has also given rise to the Transitional Labour Markets (TLM) approach (Anxo \& Erhel, 2006; Fehring \& Bessant, 2009; Schmid, 1995; Schmid, 2006). This theoretical research frame acknowledges that patterns of living and working no longer follow a traditional linear model and contends that complex transitions between different employment statuses occur across the life course and can be accompanied by social risks. Anxo and Erhel (2006) provide a useful summary of the way in which the life course paradigm, like the TLM, "releases the assumption of perfect rationality and recognizes the role of institutions and social factors in the determinants of individual behaviour" (p. 6). Importantly, they articulate that the conceptual use of the life course allows for the "usual dichotomy between agency and structure to be overcome by considering the temporal dimension of both individuals' behaviour and structural change" (Anxo \& Erhel, 2006, p. 10).

The "bi-directional relationship between individuals and their settings" (Fehring \& Bessant, 2009, p. 84), between agency and structure, implicit to this methodology results in a perspective which is complex and nuanced, alerting us to the "real world, a world in which lives are lived and where people work out paths of development as best they can" (Elder, 1998, p. 9). That such individual paths of development necessarily intersect, in multifarious ways, with the gender order should come as little surprise (Cartwright, 2008; Williams, 2000). The age range applicable to our study, spanning the late twenties to mid thirties, as Crompton and Lyonette (2011) observe, is the key point at which "gendered differences in career development" emerge (p. 246).

Significantly, the combination of social forces and individual factors (agency and structure) that is integral to life course methodology, finds parallels in the debates that have surrounded analysis of women's participation in the 
workforce. These debates, galvanised by responses to Hakim's 'preference theory' and 'orientations to work' typology (Hakim, 2002), emphasise that the exercise of choice (agency) is insufficient to explain mothers' employment patterns without due acknowledgement of the other side, namely structure (Crompton \& Lyonette, 2010; Gregory \& Milner, 2009). The essential combatability of life course theory and the social construction of gender, and the use of both as methods by which to analyse the work/care domain and women's workforce participation, is attested to by a number of authors in the field (Bruening \& Dixon, 2008; Moen \& Wethington, 1992; Moen \& Yu, 2000). The further relevance of the TLM approach is attested to by the scholarship of Schmid $(2006,2007,2011)$ and Howe (2007) and has been broadened to encompass 'the gender perspective' by Leschke and Jepsen (2009).

Women, particularly mothers, who combine paid and unpaid work during the life course, Schmid (2011) argues, "are still punished in terms of income, social security and career development" (p. 2). Tensions between the demands of paid and unpaid work, between work and care, have come to be called "work/life balance" (Caproni, 2004, p. 209). The discourse of work-life balance, when critically (and personally) analysed by Caproni (2004) reveals a foundation in "the language and logic of rational instrumentality" (p. 213), a rationality that is fundamentally at odds with care, most poignantly, with parenting. The figure of the selfless mother, in a world determined by self-interested others (Williams, 2010) points to the mismatch, or the push-pull of competing but incompatible realms. This basic incompatibility, and some of its consequences in the lives of women, of mothers, is beginning to be recognised and named, but only by an ongoing process of "opening up difficult conversations" (Williams, 2010, p. 11). The data presented in this article aims to contribute to raising the profile of issues known by scholars as the 'maternal wall' (Williams, 2000) and the 'parent trap' (Schmid, 2011); issues which remain, in mainstream discourse, part of the "unnoticed architecture of our daily lives", "the unspoken framework that shapes how we discuss work-family conflict" (Williams, 2010, p. 2).

\section{Methodology}

The Working Lives project was designed using a mixed methods approach involving a retrospective, quasi-longitudinal analysis covering a ten-year period using life course methodology (Elder \& Giele, 2009; Fehring \& Bessant, 2009; Giele \& Elder, 1998; Somekh \& Lewin, 2005). The project's scope was limited to the first 10 years of working life, on the grounds that the decade after initial education and training frequently involves crucial, risk-laden life course transitions such as leaving home, entering into long-term intimate and/or marital relationships, starting families and establishing businesses. In this article, the workforce participatory 'risks' attached to family formation, particularly for female participants, which emerged from the data will be the focus; but, the research design of the original study was deliberately exploratory. To minimize variation, however, membership of the participant sample was restricted to each participant having been: 24 years of age or under at the time of course completion; an Australian resident or citizen; and a student at RMIT from1994-1996.

The project entailed three stages of data collection and analysis, designed to retrospectively reconstruct significant events and changes in the participants' working and social lives. Stage 1 occurred in early 2007 and gathered data via a mailed, self-completed questionnaire, resulting in a total of 179 respondents (54 apprentices and 125 higher education graduates). Stage 2 involved follow-up telephone interviews of participants who agreed to further participation $(\mathrm{n}=94)$ : 29 apprentices and 65 bachelor's degree graduates. From the data gathered in Stages 1 and 2, the project provided a detailed and dynamic portrait of the ways in which qualified workers: find employment, attain promotion, develop additional skills, shape their careers and in general receive a range of benefits from their education or training (Fehring, et al., 2008).

Stage 3 of the project built on this quantitative data by providing a rich description of the motivational factors and critical events that influenced participants' decision-making at various stages of their careers. This stage involved in-depth interviews with 12 participants selected as case studies (Fehring, 2010; Fehring, et al., 2009). The participants were chosen using the purposeful sampling selection technique (Patton, 2002). Table 1 contains a brief overview of participants' details. By use of semi-structured interviews, Stage 3 captured the voices of individual workers in their thirties, giving them scope to reflect on the first ten years of their working lives and therefore on some of their met and thwarted expectations across that time, and their perspectives on the affordances and constraints relevant to their roles in the labour force (Fehring, et al., 2009).

The following section provides a brief overview of the project findings as a whole. The remainder of the article addresses the gender issues brought to light by the Stage 3 interviews. 
Table 1. Stage 3 Participants

\begin{tabular}{|c|c|c|}
\hline \multicolumn{3}{|c|}{ Higher Education Sample } \\
\hline Pseudonym & Course & Marital \& Parental Status \\
\hline Maria & Bachelor of Applied Science (Medical Radiations) & Married with children \\
\hline Maddy & Bachelor of Applied Science (Medical Radiations) & Married with children \\
\hline Melanie & Bachelor of Applied Science (Applied Physics) & Married with children \\
\hline Sue & Bachelor of Applied Science (Hospitality Studies) & Divorced, no children yet* \\
\hline Belinda & Bachelor of Applied Science (Hospitality Studies) & Married, no children yet* \\
\hline Helen & Bachelor of Engineering (Geological) & No mention of family \\
\hline Wayne & Bachelor of Applied Science (Applied Physics) & Married with children \\
\hline Colin & Bachelor of Applied Science (Construction Management) & Married with children \\
\hline \multicolumn{3}{|c|}{ Trade Sample } \\
\hline Shane & Printing-Machining & Married with children \\
\hline Simon & Plumbing-Roofing & Married with children \\
\hline Steven & Plumbing-Roofing & Married no children \\
\hline Troy & Printing-Machining & Married with children \\
\hline
\end{tabular}

* Indicates that participant volunteered information indicating an intention to start a family in the near future

\section{Overview of findings: Work, Skill, Benefit (WSB)}

\subsection{Work}

The workforce participation rates of the sample in this study are outlined in some detail in a previous working paper (Fehring, et al., 2008), but in short, these rates were influenced by gender as well as by intital type of qualification:

At the time of survey, 94 per cent of male respondents were employed full-time. [By contrast] Only 53 per cent of women were similarly engaged, with a further 30 per cent working part-time while engaged in family care, 13 per cent were not working, and an additional four per cent were on maternity leave. Just two per cent of surveyed males were unemployed and looking for work. (p. 7)

The data, across all three stages of collection, confirms that education is the key to workforce participation (Access Economics., November, 2006; Kelly, Bolton, \& Harding, November, 2005); although this statement is heavily qualified by gender and parental status. In sum, for skilled workers, there is no shortage of work, good prospects for promotion, and high levels of life satisfaction, provided you are not a female parent (Cassells, Miranti, Nepal, \& Tanton, April, 2009).

\subsection{Skill}

As indicated in a previous publication, data from the project revealed high levels of occupational retention for the skilled workers surveyed. Ten years after course completion, around 70 per cent of workers surveyed were still engaged in occupations associated with their initial qualification (Fehring, et al., 2008). Although in the original design of the project there was an intention to explore deviations between the cohorts, the data overall did not indicate a great deal of difference in satisfaction or benefit measures by cohort (that is, whether by a trade or higher education pathway). This finding is consistent with the recent findings of Karmel and Lui (10th August, 2011).

\subsection{Benefit}

Consistent with other studies of Generation X tendencies, the Working Lives Project confirmed that job enjoyment, quality of work, more flexible hours, and a more balanced life, are increasingly important aspects in the working lives of today's workforce, particularly for workers in their thirties (Bickel \& Brown, 2005; Kelly, et al., November, 2005; Rodrigues, Green, \& Ree, 2003). Indeed, a key research objective of Stage 3 was to compare and analyse participants' perceptions of their personal benefit profiles, beyond simple wage-based income.

The benefits identified by participants, beside the financial, were able to be grouped into the following categories: self employment, lifestyle change, self esteem and skill set confidence. Underpinning the first of these benefit categories was a preponderance of concerns surrounding working conditions which included: flexible work times, avoidance of shiftwork and less commuting. There was a general emphasis on lifestyle (expressed through the categories of self employment and lifestyle change). Often such emphasis revealed how much had changed in participants' priorities by their mid-thirties. During earlier times, participants explained, they were willing to put work first and to tolerate harsher conditions. 
For a number of participants a later sense of lifestyle change coincided with future plans for a family (Belinda, Sue) or with current family and caring responsibilities (Troy, Maria). Maddy, parent of one, comments "... [Shiftwork is] very lucrative... and indeed at the time when I needed the money... I was prepared to do that... But... you get a certain stage where other things become so much more important...." For some participants, especially parents, flexibility in working hours was considered a vital benefit of work, even if finding that flexibility meant changing jobs. Maria (parent of two) commented that her current "lifestyle job" which allowed her to put health and family first, had given her benefits "that you can't measure with money".

Another key underpinning theme was that of self development, expressed through the benefit categories of "self esteem" and "skill set confidence". Again, such comments reflect the point in time at which the interviews were taken: at approximately 33 years of age, and given the high occupational retention of our sample, with ten years of working life experience, participants spoke of a confidence that comes from experience, a maturity, and a sense of seniority. Belinda spoke of this, even the benefits of 'negative' experiences such as facing redundancy, because they led her to develop a wider network and helped her build her skill set. Belinda's confidence in her skills at the point of interview even led her to reveal that she had re-considered her fears about taking maternity leave (at some point in the future):

I guess, we're starting to plan a family, and what that might bring... I don't know... And that's the bit that always frightened me before, that if I left work to have a child, would I actually get back into the workforce at the same level? Whereas now I think, yeah, that's easy. Or if I don't do that, I could actually do a whole lot of other things, because I have that skill-set behind me. I've sort of got to that point now, where it doesn't matter when I leave or what I do, if I need to, I can always come back to it ... .

Several of the male participants mentioned flexibility in hours, often in conjunction with making time for family. For example, Colin spoke of self-employment as providing such benefits, and Wayne, having worked for the one company for 12 years, also mentioned that seniority had conferred on him the ability to, at times, work from home and so structure his (albeit very long) working hours around "time for the kids". In Wayne's case, it was noted that such flexibility could be achieved only after having established himself firmly in his career, and with the one company. For him, flexibility and autonomy came with having "earned" it. Similar findings were reported by Harris and Giuffre's (2010) study. Often, however, attaining such positions is only possible "after years of near-total commitment to their work" (p. 46), a situation which is out of reach for women unless child bearing is delayed.

\section{Research Findings Specifically Related to Gender}

As has been pre-empted, a number of gender-based issues arose from the Stage 3 interview data. This stage of the study involved 12 case study participants: six women and six men (Table 1). First, it is noteworthy that there were no female trade pathway participants in Stage 3. In fact, there were very low numbers of female trade pathway participants throughout the entire study. Five (of 54) female trade pathway participants took part in the Stage 1 questionnaire, of whom only two (of 29) took part in the Stage 2 telephone interviews (Fehring, et al., 2008). The observation that the vast majority of women are not choosing a trade-based career path, despite the fact that females are highly represented in the higher education sector, warrants further investigation. Scholars, such as England (2011) and Williams (2000) have addressed blockers to female trade pathways, and have identified unbending female gender-based niches and occupational segregation.

A second, more pervasive finding of the Stage 3 interviews concerned the impact of parenting on career trajectory, occasionally in the male interviews, but frequently in the female interviews. Our qualitative data gives voice to feelings of frustration, loss of identity, self-depreciation, and the emotional strain of balancing working life with motherhood. The following five points summarise the nature of this impact of parenting on workforce participation.

1) Once a parent, there was a tendency to find oneself in, or to feel the need for, a job that was relatively un-demanding, in terms of time and in terms of self. Often these were also considered low-interest and low-satisfaction jobs (expressed by Maddy, Maria and Melanie). These types of jobs are often referred to as the 'mummy track' (Pocock, 2003; Webber \& Williams, 2008). Becker and Moen's (1999) research also refers to the job versus career choice, where one partner scales back from career to job, most often the female partner (Francis, Lingard, \& Gibson, 2006, August; Webber \& Williams, 2008).

2) Once a parent, there was a tendency to become stuck in a field, without the time or resources to retrain in order to effect a career shift. This was noted by Maria: “I suppose that's why I don't enjoy [my profession] anymore, because I'm stuck. ... Stuck! And I don't have the time to put into continuing education to move forward." Similar comments were voiced by Melanie, and interestingly, also by one of the male trade 
participants, Shane. All three comments were underpinned maternity leave issues (for self or partner): issues of its timing and of it placing financial constraints on re-training; all three participants were seeking workforce re-entry and pathway change.

3) Parenthood for women often entailed juggling either concurrent part-time jobs (Maddy worked two days for one practice and two days for another, in order to achieve the part-time hours she needed) or a series of part-time jobs (Maria). This routine made for complex and hectic lives and demanded additional effort in the negotiation of terms of paid work (Morehead, 2003; Stone, 2007; Williams, 2010).

4) In the transition to part-time work and/or during a period of maternity leave, case study participants reported a loss of personal income and with it a perceived loss of power, and of self. Maria spoke candidly of this, as did Melanie. Williams (2010) and Stone (2007) both explore the painful loss of status attached to this transition.

5) Job change was often assumed of female parents. Maria, in particular, expressed a sense that the disruption of her career on becoming a parent was "just assumed" as opposed to any career change being imposed upon, or expected of, her male partner. "I don't think we ever made a decision, I think it just evolved... it was always going to, I don't know how it actually arose" [that I should step aside from my profession]. Very similar comments were documented in the research by Francis, Lingard and Gibson (2006) where participants used the terms "evolved" and it "just worked out that way" (p. 18). The unspoken, unquestioned, almost unnoticed, element vocalised by these case study participants reflects the cultural habitus of motherhood (Cartwright, 2008; Williams, 2000).

On each of the five points noted above, there has been considerable scholarship and debate published. What stood out from the current interview data, however, were the following three further corollaries.

6) Our participants were shocked and, in essence, blindsided by the changes to their career trajectories wrought by the transition to motherhood. So much so, that they repeatedly expressed disbelief, conveying the sense that 'in this day and age, I didn't think I would have to choose' [between career and parenting]. Their skill level and seniority, it seemed, had been perceived as a form of insurance against inflexible workplaces and poor conditions (Schmid, 2011; Williams, 2000). This expectation, it was noted above, was also expressed by male participants, whereby a certain seniority implied having earned a measure of workplace flexibility. But for the mothers of our study, this proved to be false insurance. When it came to the crunch, these women were forced to choose between career and family: which of course, is no choice at all (Cartwright, 2008; Pocock, 2005; Pocock, Skinner, \& Williams, 2008; Williams, 2000; Williams, 2003-2004).

7) When faced with the all or nothing workplace (Williams, 2010), these women were pushed out. In each case, transition back to work after maternity leave was made all-but-impossible. In two cases, participants were refused a reduction in work hours (i.e. to work part-time rather than full-time), and in a third, her position was fundamentally changed upon return. Often this is depicted as opting out (Stone, 2007; Williams, 2010) and indeed, in these women's interviews they make reference to choice. However, use of the word choice is now enormously contested.

8) In the period following childbirth and re-entry to the workforce, a model of three adaptive strategies/approaches was discernable. This model can be summarised as:

i. Acceptance of the status quo, but forging an individual solution (exemplified by Maddy)

ii. Self-employment as an escape route (exemplified by Maria) and,

iii. Stalemate or Discontent (exemplified by Melanie).

The trajectories and transitions of these participants were similar in nature, centred on their dual roles as worker and carer. Each participant's acknowledgement, reaction and response to such transitions, however, differed markedly, and in ways that deserve discussion.

\subsection{The Impact of Parenting}

1) Maddy: Acceptance of Status Quo and Own Solution

Maddy articulated an awareness of female gender constraints but expressed a willingness to accept the status quo and to work within its limitations. When asked to reflect on her return to work after childbearing, Maddy described the intractability of her manager who refused to entertain the idea of job sharing, despite ten years of service and, in Maddy's words: "there being nothing preventing us from doing that - which is one of the reasons... why I chose this profession because I knew that [job share] would be something I could do quite easily in the future". 
Nonetheless, Maddy betrayed "no hard feelings" toward her manager, saying:

... At the time the general chief was not happy to do job-share. I think-I don't know whether he'd had other people try before and it had not worked out in relation to holidays, sick leave, all that sort of thing - I think he just felt it was all too complicated.... But, you know - nothing against him, it's fine... You know, it's all okay.... I think, look, it's just, you know, some people are fairly stuck in their ways and don't want to change.

Maddy's acceptance of the status quo and its limitations reflect what many argue is the most common female response to the work/care collision (Pocock, 2003; Webber \& Williams, 2008). She doesn't look for, or expect, assistance instead she finds ways round the situation. In Maddy's case her solution was to resign and find a combination of part-time jobs, close to home, in order to accommodate the demands of her family life.

At the point of interview, Maddy worked two part-time jobs to enable her to achieve the school hours that she needed. In Webber and Williams' (2008) words, she "had patched together" (p. 767) an individual solution. Significantly, by her repetition of the phrase "it's okay", Maddy indicated a willingness to take personal responsibility and to absolve her former employer. Far from considering herself having suffered career penalties, Maddy felt fortunate to have achieved the part-time hours she had (Sabelis, Nencel, Knights, \& Odih, 2008).

2) Maria: Self Employment as an Escape Route

Like Maddy, Maria was also unable to secure a job share position (in her supervisory role) on her return from maternity leave. She described being overlooked for training, having to step down from her supervisory position and, eventually, from her field of specialisation (because she was unwilling to be placed on an on-call roster). She explained:

I think it's always been assumed [that being full-time is] part and parcel of the nature of the job. I know when I was [there] they never took people back part-time. It was full-time or nothing... there is this cultural thing that you need to be there full-time to have a position of charge.

Having been forced to move sideways, outside her field of specialisation, Maria described a loss in job quality and satisfaction: "I was still relatively happy, but I got bored very fast. And that's when I realised, "Oh! I was a bit short sighted there." Maria's next step was to combine several part-time jobs, like Maddy. After finding this too difficult to juggle, she decided to leave her profession entirely, and work in her husband's business, she describes her reasoning:

We just found that life was hectic and busy and ...there was no room for anything to happen. It was just too hard - so we were struggling the minute one of us felt slightly sick or not up to a hundred percent ....

This initial solution put in place by Maria had been established some years before being interviewed. Maria expressed considerable acceptance when initially forced to sacrifice her seniority, and only on reflection seemed to acknowledge how difficult this had been:

I did it [resigned] and went, 'Oh my gosh, what have I done?' Because I'd been there about ten years. Then, yeah, it went to a stage of ... once I'd had a few weeks... it was so much nicer not to be so tired, so run off my feet and just rushing and...On the whole, I can be there for my kids and that's really, really the most important thing on our agenda at the moment... [But... when I think of my profession] ... I miss it, and there's bits I found really hard about giving up. I felt like I lost a bit of me, felt it was the only thing that was mine, outside of my family, so I didn't like that. And then I realised... I'd worked for this degree and now I've just said 'See ya' without giving it much thought-it felt like I hadn't given it much thought, but it had been brewing for a while; but yeah it was really hard to turn your back on it and say it doesn't mean anything, but it does.

In contrast to Maddy, Maria articulates grief and loss: "I felt like I lost a bit of me". Underlying Maria's words there is a grappling with the meaning that culture attaches to 'work, 'qualifications' and 'self' (Schultz, 2000). She described her career as "a bit of me ... the only thing that was mine", and her qualification as something she had "worked for" but then "turned her back on". Maria went on to explain some of the other losses she had suffered, both minor rewards (such as promotion, appreciation, recognition) and of course, remuneration.

As noted above, this transition in Maria's life seemed to sneak up on her. She explains:

Look, I don't think we ever made a decision, I think it just evolved; and sometimes that's hard, because you think, 'Hey do you [husband] realise ... I've given up my... [qualification]'....

In the clash between Maria's and her husband's career, it was Maria who downgraded to a job; somehow "it just happened", with Maria reflecting ("I knew he'd always have his own business.... He had always said he wanted his own practice and it was just - my role was just that - it was just assumed".) As Webber and Williams (2008) argue: 
"Gender is precisely what makes it "okay" for his "choice" to stay on the fast track while she scales down her career" (p. 761).

Maria's particular response to workplace marginalisation was to seek self-employment, which, as Williams (2000) notes, has become a common escape from the juggle. But as Williams (2010) also notes, often relief "at escaping the hydraulic pressures of their former lives" was offset by participants' "real regrets" (p. 17). In Maria's case, self-employment in her husband's business, has given her "an awesome lifestyle benefit, that I can work, but have my family as well, and I don't know too many people that get that flexibility". Grateful indeed to have found a solution to the impasse of work and care, Maria still concedes that it's "a hard time in life when you've got little kids and your husband is building his career", so much so that she is willing to deviate down the mummy track for a period (into something not too "demanding" or that does not have "too much responsibility").

Shapiro, Ingolis and Blake-beard (2007) describe self employment as the new career paradigm (even for women who are not strictly self-employed). However, as Lowe (2002) warns, such an escape route can carry hidden costs:

...the shift from standard to non-standard forms of work has been illustrated in the rise of self-employment, temporary work, and decentralized work locations [such as working from home].... Among [Canada's] self-employed individuals, one in four access medical and dental benefits through spousal benefit plans... the vast majority lack pensions, sick leave protection or paid maternity leave - all of which puts added social psychological, and economic strains on families. (p. 97)

Maria's closing comments in her interview acknowledge some level of cost, but also convey some resignation that, for her, this cost seems to be a female gender-based burden:

I think for any woman in today's world where you try to balance everything, you work yourself up to a point - and I don't know many people that haven't given away something to have a family, and it depends on how much that means to you. But I think it is a fallacy if you believe you can have both ... I do believe it's very hard to have a job that you feel very satisfied in... that's very job-satisfying, that you've worked up to, and has any kudos, and have a family and have that time with that family. I know all of my friends have given up some element of their work to raise their family. Whether they go back to it, they might, I don't know, but, yeah....

Maria concedes that perhaps this is a transitional time, "whether they go back to it" is unknown, but what she does know is that there are real career costs at this particular moment of supposed career crescendo ("you work yourself up to a point").

The third adaptive strategy of our model is illustrated by Melanie. However, before moving to case study 3 , it is important to note that, within the context of their interviews, Maria and Maddy both expressed an unwillingness to "fight" for family-friendly working conditions. Both women described a reluctance to "make a fuss" by attempting to achieve conditions that would allow them to remain at their current workplace while parenting. Both participants seemed unwilling (in Maddy's words) to "cause trouble", that is, unwilling to "force" change by taking formal action. Maria articulates this unwillingness, but also some regret:

I don't know if I could've pushed for it and maybe - you know, if you threatened legal action or something you probably would get your way, but depends if you want to go down that path, or feel comfortable or not, and I've never been one to threaten and that so... and I wasn't really interested-I was a bit naïve and didn't really realise how much I probably needed to have that day a week.

Maddy similarly “didn't push too hard” for a job-share position; she resigned instead, having decided she was "not going to cause any trouble." For Maddy, an aversion to "hav[ing] to keep fighting and arguing... to keep, you know, hassling or trying for" promotions and better working conditions, were a recurrent feature of her interview. For example: "I'm not a person who likes to just, you know, keep nagging, keep, hassling people [about a pay rise]- let's get on with the work and let's do it, you know."

In both these instances it is the worker's response to workplace marginalisation that is remarkable. As Emslie and Hunt (2009) commented (of their participants): "it is striking that work-life balance was perceived as a personal issue to be dealt with using individual strategies and not as a structural problem caused by a lack of flexibility in the workplace" (p. 168). Several studies confirm the importance of informal and ad hoc measures to the management of work-life balance (Becker \& Moen, 1999; Harris \& Giuffre, 2010). In Australia, Burgess, Henderson and Strachan (2006) conclude from their study a surprising level of acceptance, similar to that expressed by Maddy above. In their words, "most women were accepting of the practices in place in their workplace.... Put simply, they did not seek more than was offered" (Burgess, Henderson, \& Strachan, 2006, p.1).

As Emslie and Hunt (2009) argue, trying to access respondents' accounts of work-life balance can be difficult, because such questions traverse personal issues which are intimately tied to constructions of identities and are 
thereby potentially sensitive. In their study they noted that participants' narratives "...suggest that they initially tried to minimize problems with work-life balance, instead noting that they 'coped' and 'just got on with it"' ( $p$ 168). Such responses, particularly reflecting Maddy's position (above), may well be bound up in perceptions of the 'good mother'(Emslie \& Hunt, 2009); one who persists despite challenging conditions, even containing an element of denial. But such denial comes at a cost, and it again recalls the notion of a cultural habitus of motherhood (Cartwright, 2008). The third case study, Melanie, speaks exactly to the issues of access and non-denial.

3) Melanie: Stalemate and Discontent

Unlike case studies 1 (Maddy) and 2 (Maria), who reflect on earlier responses to maternity leave transition, Melanie's experience of difficulty on re-entry to the workforce is contemporaneous. At the point of interview, Melanie had been back at work only three weeks (since taking her second period of maternity leave), but was on the brink of resignation, her levels of dissatisfaction were so high. Having lost all her clients to a staff member of which she had previously been manager, when asked about her return from maternity leave and her reorientation to work, Melanie was critical:

Look they don't support [you] at all- I think they're almost annoyed with part-time workers at [my workplace], I think they like to see themselves as - you know - employer of the year for females, but they certainly don't have any, you know, real loyalty I think too- to people returning from maternity leave. And they don't see a benefit of someone working three days.

As Melanie continues, she acknowledges the "normative male archetype" (Pocock, 2005, p. 32), only to concede its inappropriateness in her situation.

I always saw myself progressing through the ranks in that normal sense and achieving different things and not stopping, ... now that I've had children, and I'm often feeling... confronted or angry by the fact that now things stop for a certain amount of time and that men don't have that same kind of... [limitation]... And you know, like, that's probably coming to terms with being female - and I'd-you know, much rather have children than a career, but I wouldn't ever have one or the other, so I think that ... I need both in my life. So I guess the idea of career has changed in that I just can't - like right now I just can't do what is needed'cause it doesn't sit with me, I wouldn't leave the children, I wouldn't work full-time ... So my idea's definitely[changed]. I think I had a fairly idealistic idea of, you know, how you can get yourself to a certain level and then be able to at least maintain it - whereas that hasn't necessarily happened.

Interestingly, Melanie had once believed that her career would be self-sustaining; and yet, as a result of her experience, she now maintains that maternity leave, and/or a period of part-time work "can stop a career"; a career needs continual development ("if I'm not developing, then I'll still be behind the game"). It is indeed remarkable that Melanie's experience seems to directly speak to, even refute, the comments made by Belinda, as noted above. Belinda, who was not (yet) a mother, made an explicit comment expecting her skill set to facilitate an easy transition back into the workforce after maternity leave, referring to it as if it were a form of insurance (Schmid, 2011; Williams, 2010). Melanie's experience seems to refute this assumption. She even states that she has now come to see this view as "fairly idealistic".

Melanie openly and passionately described her sense of frustration: "Ijust can't do what is needed". She expressed a sense of being torn between career progression and parenting. She described feelings of being "confronted or angry" about the way in which her career had stalled, a process of "coming to terms with being female". Like Maria, she spoke of "having lost something" and yet conveys a sense of being somewhat mystified as to how that happened. She articulates disbelief as to how she has been devalued as an employee.

I'm still coming to terms, I guess, with how it all happens... it's like, all of a sudden, you have two children and you're less valuable as an employee. ... I feel it's really unjust. I'm a relatively intelligent person and yet, you know, I can't see any way to really progress career-wise ... I can't see another way round it, like you can only bang your head against things for so long and stuff, so, yeah, I don't know. I do - I constantly feel annoyed about it....

For Melanie, the consequences of her maternity leave impact on: job quality, skill atrophy, and future job opportunities (Baird \& Charlesworth, 2007; Barns \& Preston, 2010). Her words powerfully articulate these consequences:

I have two small children that I will have - until they're at school-age and even then some-but until they're at school age they'll be a large part of my responsibility... I can't -I don't have certain options in terms of career and choices in terms of that sort of stuff, so, y'know, I-yeah, I guess, I see it as temporary, but who knows what it'll be like in five years time?... And I don't think any industry will allow you to stand still, for 
five years! I mean, while you wait for the kids to get old enough-so, I don't really know, I can't see past, y'know, right now at the moment, I just - like, I can't see a future where I'm back on track, career-wise... I think that I'll be by-passed by either people who have [made] different choices in life, who don't necessarily have kids, or they're male, and they have kids regardless. But-you know, I see it happening now, I see more junior staff, less experienced staff, moving ahead... I can't see any other way at the moment, and I can't see when I'll suddenly be - I can't see a point when I'll be back on my career-path, where I-[will be] where I want to be. I can't see that at all...

The real significance of Melanie's interview relates to its timing. When Melanie is interviewed her marginalisation is in progress and her response is raw and angry. She paints a bleak portrait of a person alienated by the workplace, unsure of how to battle what she perceives as injustice: "I can't see another way round it, like you can only bang your head against things for so long and stuff, so, yeah, I don't know." By capturing this discontent, Melanie's interview offers insight into the potential risks of this transition. She believes she does not have "certain options in terms of career and choices"; indeed she can't "see past... right now ... [to] a future where I'm back on track".... When pressed (by the interviewer) about any 'benefits' of two beautiful children, Melanie continues:

I love having kids...- but it's not enough on its own, I wouldn't want to be just having kids, I wouldn't just want to have career, like you know, so ... I'm not happy to let things go... I'm not happy to just stop for five years or so. I'm not happy just to be a mother because I need to be more... Yeah, so while I accept it as being what it is for now, and my decision is to be there for the kids as much as I can be, I-it's not necessarily just what I want. And I don't feel resentful, entirely, I'd rather be there [with the kids] - it's my choice to not [work full-time]...

Interestingly, even Melanie speaks briefly of choice, whilst identifying an impasse, or her seeming lack of choice. In all three case studies, the language of choice used is problematic. As Webber and Williams (2008) argue, the women's stories actually reveal the existence of a choice gap. Choice rhetoric, Williams (2000) has repeatedly argued, "obscures the structural constraints and absolves organizations" (p. 14). Such language reinforces the emphasis on 'individual solutions' (Harris \& Giuffre, 2010) which, as many feminist scholars now acknowledge, arguably "reinforces the existing collective gender order that reproduces gender inequity" (Sabelis, et al., 2008, p. 427) (Moen \& Yu, 2000; Yerkes, et al., 2010). Again, Webber and Williams (2008) express this passionately:

This gendered organization of work amounts to a structural straightjacket that seems to preclude any practical or imaginative resistance to unequal treatment at work. Instead, [participants]... use the language of "choice" to explain their situation, which absolves their employers from responsibility for exploiting and discriminating against them. Structural constraints are transformed into preferences, concealing the injustice of their situation. (p. 772)

Melanie's response to workplace marginalisation refuses to conceal the injustice. This is the real benefit of her interview. She vocalises stalemate and anger and perhaps without that, change will not happen. If grievances are a precondition to mobilization, (Andrew, 2008, p. 375) then Melanie's anger might be useful.

The prominence of comments in Maddy and Maria's interviews concerning an unwillingness to push or fight, and their similarity, was a striking finding of the Stage 3 qualitative data. Is it simply a coincidence that both of these case study participants felt unwilling, or unable, to take a political stand in order to achieve the work-life balance they needed to remain working within their careers? Such a coincidence becomes even more remarkable when contrasted with the male and non-mother participants of Stage 3, who voice an expectation of flexibility which comes with seniority. To recap, increased confidence in skill set was spoken of by many as a benefit of work, particularly manifest as a sense of seniority that made better working conditions expected (Wayne, Colin, Helen and Belinda). By contrast, Maddy and Maria (above) lacked enough confidence in their place in the workforce to push for better conditions. When it came to the crunch, the ones who really needed such flexibility, found it beyond their reach.

All three case studies experienced marginalisation as a consequence of maternity leave, but two could barely recognise, not to mention articulate, this process of loss. Instead there seems to be some collusion between the cultural habitus of motherhood and a 'just get on with it' work ethic (particularly in Australia) which valorises those who don't complain. There is a lack of acknowledgement that the gender order constrains, and that there is a lack of institutionalised support to combat such constraints. Whilst this denial continues, change will not be forthcoming. The crescendo of angst expressed by these women serves as a reminder that there is much still to be done. The first step is to recognise that there is ongoing gendered inequality in the work-life experiences of Australians. 
Williams' (2010) powerful critique of the "opt out narrative" that peppers the popular media serves as a reminder of how easily issues of "work-family conflict" can be manipulated, framed as a "woman's issue", and diminished as a "champagne problem" (p.14). The voices of the Stage 3 mothers from the Working Lives project indeed draw attention to problems, that Williams argues, are so often fictionalised by the opt out narrative. These are: that time out of career can be unrecoverable (Melanie) and that women are much more conflicted about their choices than is represented in the popular media (Maddy and Maria). At the time of interview, our participants were genuinely shocked that these things could happen to them. Emphasis needs to be placed more on public policy and moved away from the individualised solution, with its accompanying imagery of the individual 'coper' who 'juggles' and 'balances' (Pocock, et al., 2008).

\section{Conclusion}

The angst expressed by this sub-sample of the Working Lives project, as they attempt to manage the tug of war between work and care, arguably reflects the political landscape of Australia across this period. This tousle involves, first, the push into the workforce (fuelled by concerns as to ageing population demographics and skill shortage discourse); secondly, the pull toward full-time mothering, whether simply from the "absolute need for human care and nurturing" (Crompton \& Lyonette, 2011, p. 249) or by financial disincentives to work (Brennan, 2007; Hill, 2006); thirdly, the losses incurred by stepping out of the workforce (both personally and financially, and compounded by divorce (Cassells, et al., April, 2009; Schmid, 2011), and then the final push out by inflexible conditions (Williams, 2010).

The voices of these women in their thirties whose careers have undergone phases of transition between care and career seem to confirm Schmid (2007) and Macdonald and Holm's (2001) perspectives that this period of the life course can contain the most challenging risks:

... when people have to manage, simultaneously, increasing risks related to work, education and care.... Failure to manage these risks will inevitably lead to increased labour market segmentation, reduced quality of life, unstable families and probably a further reduction in the size of families. (Schmid, 2007, p. 11)

Schmid's identification of 'the compressed career' particularly isolates the risks attached to transitions surrounding motherhood $(2006,2011)$. Whilst it might be argued that such a period is transient or temporary these temporary measures have knock-on effects for female career trajectories and wage gaps that are long lasting and pervasive (Williams, 2000). Such gaps are significant. Cassells, Miranti, Nepal and Tanton (April, 2009) argue that, where children are present, the lifetime earnings for a man could be double that for a woman $(\$ 2.5$ million compared to $\$ 1.3$ million). It is high time such risks are brought into mainstream consciousness, rather than being left to blindside contemporary women workers who are still at risk of being misled by the opt out narrative. The recent study by Baker (2011), which attempts to quantify the wage penalty effect of maternity leave in Australia, marks a much needed beginning. That such penalties are still subject to "little public discussion in Australia" (Baker, 2011, p. 15) is testimony to the discomfort that this issue evokes, and to the essential incompatibility of economic rationality and the act of parenting (Caproni, 2004; Duncan, Edwards, Reynolds, \& Alldred, 2003; Yerkes, et al., 2010). As Pocock (2003) argued, now almost a decade ago, "the basic assumptions of neo-classical economics - 'economic man' - are contradicted by care" (p. 16). It is high time this contradiction was confronted.

\section{Acknowledgements}

Mr Jeff Malley original ARC team member 2006 - 2009.

\section{References}

Access Economics. (November, 2006). Meeting Australia's ageing challenge: The importance of women's workforce participation. Retrieved 18th August, 2011, from http://www.accesseconomics.com.au/publicationsreports/getreport.php?report=115\&id=152

Acker, J. (1990). Hierarchies, jobs, bodies: A theory of gendered organizations. Gender \& Society, 4(2), 139-158. http://dx.doi.org/10.1177/089124390004002002

Andrew, M. (2008). Questioning women's movement 'strategies': Australian activism on work and care. Social Politics, 15(3), 369-395. http://dx.doi.org/10.1093/sp/jxn012

Anxo, D., \& Erhel, C. (2006). Irreversibility of time, reversibility of choices? The life-course foundations of the transitional labour market approach. Paris: Centre d'Economie de la Sorbonne, Universite Paris.

Baird, M., \& Charlesworth, S. (2007). After the baby: A qualitative study of working-time arrangements following maternity leave. Labour \& Industry, 17(3), 97-118. 
Baker, D. (2011). The wage-penalty effect. The hidden cost of maternity leave. Policy Brief No 24, July 2011. Retrieved https://www.tai.org.au/file.php?file=/media_releases/PB\%2024\%20The\%20wage-penalty\%20effect.pdf. http://dx.doi.org/10.3386/w17105

Barns, A., \& Preston, A. (2010). Is Australian really a world leader in closing the gender gap? Feminist Economics, 16(4), 81-103. http://dx.doi.org/10.1080/13545701.2010.530607

Bartel, A. P. (2000). Measuring the employer's return on investments intraining: Evidence from the literature. Industrial Relations, 39(3), 502-524. http://dx.doi.org/10.1111/0019-8676.00178

Becker, P. E., \& Moen, P. (1999). Scaling back: Dual-earner couples' work-family strategies. Journal of Marriage and the Family, 61, 995-1007. http://dx.doi.org/10.2307/354019

Bickel, J., \& Brown, A. J. (2005). Generation X: Implications for faculty recruitment and development in $\begin{array}{lllll}\text { academic health } & \text { centres. } & \text { Academic }\end{array}$ http://dx.doi.org/10.1097/00001888-200503000-00003

Blundell, R., Dearden, L., \& Sianesi, B. (2004). Evaluating the impact of education on earnings in the UK: models, methods and results from the NCDS (WP 03/02). London: Institute for Fiscal Studies, UK.

Brennan, D. (2007). Babies, budget, and birthrates: Work/family policy in Australia 1996-2006. Social Politics, 14(1), 31-57. http://dx.doi.org/10.1093/sp/jxm003

Bruening, J. E., \& Dixon, M. A. (2008). Situating work-family negotiations within a life course perspective: Insights on the gendered experiences of NCAA division I head coaching mothers. Sex Roles, 58, 10-23. http://dx.doi.org/10.1007/s11199-007-9350-x

Burgess, J., Henderson, L., \& Strachan, G. J. (2006). 'I just juggle': Work and family balance in Australian organisations. Our work ... our lives: National Conference on Women and Industrial Relations. Proceedings of the 1st Biennial Conference of the National Network of Working Women's Centres Retrieved 7th September, 2011, from hhtp://hdl.handle.net/1959.13/34245

Burgess, J., \& Strachan, G. (2005). Integrating work and family responsibilities: Policies for lifting women's labour activity rates. Just Policy, 35, 6-12.

Caproni, P., J. (2004). Work/Life balance. You can't get there from here. The Journal of Applied Behavioral Science, 40(2), 208-218. http://dx.doi.org/10.1177/0021886304263855

Cartwright, S. (2008). The shifting paid work and family life experiences and ultural habitas of motherhood: An Australian perspective. The international Journal of the Humanties, 5(12), 139-149. Retrieved 20th October 2011, 2011, from http://www.Humanities-Journal.com

Cassells, R., Miranti, R., Nepal, B., \& Tanton, R. (April, 2009). AMP. NATSEM Income and Wealth Report, Issue 22. She works hard for the money. Australian women and the gender divide. Canberra, ACT: University of Canberra.

Craig, L., Mullan, K., \& Blaxland, M. (2010). Parenthood, policy and work-family time in Australia 1992-2006. Work, Employment and Society, 24(1), 27-45. http://dx.doi.org/10.1177/0950017009353778

Crompton, R., \& Lyonette, C. (2010). Family, class and gender 'strategies' in mothers' employment and childcare. In J. Scott, R. Crompton \& C. Lyonette (Eds.), Gender inequalities in the 21st century: New barriers and continuing constraints (pp. 174-192). Cheltenham, UK: Edward, Elgar Publishing.

Crompton, R., \& Lyonette, C. (2011). Women's career success and work-life adaptations in the accountancy and medical professions in Britain. Gender, Work and Organization, 18(2), 231-254. http://dx.doi.org/10.1111/j.1468-0432.2009.00511.x

DEECD (April, 2010). Working lives: Trade and bachelor graduates ten years on. ARC Linkage study 2006-09 (LP0667939). Retrieved 12th November, 2011, from http://www.education.vic.gov.au/

Duncan, S., Edwards, R., Reynolds, T., \& Alldred, P. (2003). Mootherhood, paid work and partnering: Values and Theory. Work, Employment and Society, 17(2), 309-330. http://dx.doi.org/10.1177/0950017003017002005

Elder, G., H. (1998). The life course as developmental theory. Child Development, 69(1), 1-12. http://dx.doi.org/10.2307/1132065

Elder, G. H., \& Giele, J. Z. (Eds.). (2009). The craft of life course research. New York: The Guilford Press. 
Emslie, C., \& Hunt, K. (2009). 'Live to work' or 'work to live'? A qualitative study of gender and work-life balance among men and women in mid-life. Gender, Work and Organization, 16(1), 151-172. http://dx.doi.org/10.1111/j.1468-0432.2008.00434.x

England, P. (2011). Reassessing the uneven gender revolution and its slowdown. Gender \& Society, 25(1), 113-123. http://dx.doi.org/10.1177/0891243210391461

Fehring, H. (2010). ARC Linkage LP0667939 reports Stage $1 \& 2$ and Stage 3. Retrieved 25th April, 2010, from http://www.rmit.edu.au/browse;ID=0rmaoy8jxuwwz

Fehring, H., \& Bessant, J. (2009). Life course research design for transitional labour market research. Journal of Education and Work, 22(2), 81-90.

Fehring, H., Malley, J., \& Herring, K. (2009). Working lives project. A ten-year comparative analysis of work, benefit and skill trajectories of parallel cohorts of trade and bachelor graduates. Report of Stage 3 (Unpublished research report). Melbourne: RMIT University.

Fehring, H., Malley, J., \& Robinson, L. (2008). The first ten years of working life: The experiences of those with trade and bachelor degree qualifications. Working Paper Series 2008 Paper No. 4 Retrieved 10th March, 2009, from http://www.rmit.edu.au/browse;ID=t98bmwrxlc9

Fevre, R., Rees, G., \& Gorard, S. (1999). Some sociological alternatives to Human Capital Theory and their implications for research on post-compulsory education and training. Journal of Education and Work, 12(2), 117 -140. http://dx.doi.org/10.1080/1363908990120201

Francis, V., Lingard, H., \& Gibson, A. (2006, August). A qualitative study of work-life experiences in the public and private sectors of the Australian construction industry. Brisbane, Queensland: Construction Industry Institute Australia Inc., Queensland University of Technology.

Giele, J. Z., \& Elder, G. H. (Eds.). (1998). Methods of life course research. Qualitative and quantitative approaches. Thousand Oaks, CA: Sage Publications.

Gregory, A., \& Milner, S. (2009). Editorial: Work-life balance: A matter of choice? Gender, Work \& Organization, 16(1), 1-13. http://dx.doi.org/10.1111/j.1468-0432.2008.00429.x

Hakim, C. (2002). Lifestyle preferences as determinants of women's differentiated labor market careers. Retrieved 20th November, 2007, from http://wox.sagapub.com. http://dx.doi.org/10.1177/0730888402029004003

Harris, D. A., \& Giuffre, P. (2010). "The price you pay": How female professional chefs negotiate work and family. Gender Issues, 27, 27-52. http://dx.doi.org/10.1007/s12147-010-9086-8

Hill, E. (2006). Howard's 'choice': The ideology and politics of work and family policy 1996-2006. Australian Review of Public Affairs. Retrieved from http://www.australianreview.net/digest/2006/02/hill.html

Howe, B. (2007). Weighing up Australian values. Balancing transitions and risks to work and family in modern Australia. Sydney, NSW: University of New South Wales Press Ltd.

Jamieson, L., \& Morton, S. (2005). Work-life balance across the lifecourse. Research Briefing 21. Edinburgh: Centre for Reserach on Families and Relationships (CRFR).

Jaumotte, F. (2003/02). Labour force participation of women: Empirical evidence on the role of policy and other determinants in OECD countries. OECD Economic Studies, 37, 51-108. Retrieved 19th September, 2011, from www.oecd.org/dataoecd/12/39/34562935.pdf

Jeanes, E. L., Knights, D., \& Martin, P. Y. (Eds.). (2011). Handbook of gender, work and organization. Chichester, West Sussex, UK: John Wiley \&Sons Ltd.

Karmel, T., \& Liu, S.-H. (10th August, 2011). Which paths work for which young people? NCVER Longitudinal Surveys of Australian Youth (LSYAY) Research Report 57. Retrieved from http://www.ncver.edu.au/publications/2397.html

Kelly, S., Bolton, T., \& Harding, A. (November, 2005). AMP. NATSEM Income and Wealth Report Issue 12. Changing face of the Australian labour force 1985 - 2005. May the labour force be with you. Sydney, NSW: National Centre for Social and Economic Modelling Pty Ltd (NATSEM), AMP.

Leschke, J., \& Jepsen, M. (2009). Transitional labour markets, from theory to policy application. Can transitional labour markets contribute to a less traditional gender division of labour? Documents de Travail du Centre d'Economie de la Sorbonne. CES Working Papers No. 27. 28. Retrieved from http://ces.univ-paris1.fr/cesdp/CES-docs.htm 
Lowe, G., S. (2002). Employment relationships as the centrepiece of a new labour policy paradigm. Canadian Public Policy-Analyse De Politiques, XXVIII(1), 93-104. http://dx.doi.org/10.2307/3552163

Macdonald, F., \& Holm, S. (2001). Employment for 25-to34-year olds in the flexible labour market: A generation excluded? Growth, 49, 16-24. Retrieved 7th September, 2011, from http://search.informit.com.au/documentSummary; $\mathrm{dn}=351635154607781$;res=IELBus

Maddison, S., \& Partridge, E. (2007). How well does Australian democracy serve Australian women? Report No. 8. Canberra, ACT: Democratic Audit of Australia, School of Social Sciences, Australian National University.

Mayer, K. U. (2000). Promises fulfilled? A review of 20 years of life course research. Archives Europeennes de Sociologie, XLI (2), 259 - 282. http://dx.doi.org/10.1017/S0003975600007049

McIntosh, S. (2002). Further analysis of the returns to academic and vocational qualifications (No. RR370). London: Centre for Economic Performance, London School of Economics.

McIntosh, S. (2005). Using pseudo cohorts to track changes in the qualifications of national populations (No. RR 621). London: Centre for Economic Performance, London School of Economics.

Moen, P., \& Wethington, E. (1992). The concept of family adaptive strategies. Annual Review of Sociology, 18, 233-251. http://dx.doi.org/10.1146/annurev.so.18.080192.001313

Moen, P., \& Yu, Y. (2000). Effective work/life strategies: Working couples, work conditions, gender, and life quality. Social Problems, 47(3), 291-326. http://dx.doi.org/10.2307/3097233

Morehead, A. (2003). Managing flexible working time arrangements: Negotiations between mothers and managers in a Canberra hospital. Labour \& Industry, 14(1), 91-106.

Patton, M. Q. (2002). Qualitative research \& evaluation methods (3rd ed.). Thousand Oaks, CA: Sage Publications.

Pocock, B. (2003). The work/life collision. What work is doing to Australian and what to do about it. Leichhardt, NSW: The Federation Press.

Pocock, B. (2005). Work/care regimes: Institutions, culture and behaviour and the Australian case. Gender, Work and Organization, 12(1), 32-49. http://dx.doi.org/10.1111/j.1468-0432.2005.00261.x

Pocock, B., Skinner, N., \& Williams, P. (2008). Work-life outcomes in Australia: Concepts, outcomes and policy. In C. Warhurst, D. R. Eikhof \& A. Haunschild (Eds.), Work less, live more? Critical analysis of the work-life boundary (pp. 22-43). New York, NY: Palgrave MacMillan.

Ramazanoglu, C., \& Holland, J. (2002). Feminist methodology. Challenges and choices. London: SAGE Publications Ltd.

Richardson, S. (2007). What is a skill shortage? Adelaide, SA: NCVER. http://dx.doi.org/10.1158/0008-5472.CAN-07-2536

Rodrigues, R. O., Green, M. T., \& Ree, M. J. (2003). Leading generation X: Do the old rules apply? The Journal of Leadership and Organizational Studies, 9(4), 67-75. http://dx.doi.org/10.1177/107179190300900406

Ruspini, E. (1999). Longitudinal research and the analysis of social change. Quality and Quantity: European Journal of Methodology, 33(3), 219-227. http://dx.doi.org/10.1023/A:1004692619235

Sabelis, I., Nencel, L., Knights, D., \& Odih, P. (2008). Editorial: Questioning the construction of 'balance': A time perspective on gender and organization. Gender, Work \& Organization, 15(5), 423-429. http://dx.doi.org/10.1111/j.1468-0432.2008.00411.x

Schmid, G. (1995). A new approach to labour market policy: A contribution to the current debate on efficient employment policies. Is full employment still possible? Transitional labour markets as a new strategy of labour market policy. Economic and Industrial Democracy, 16, 429-456. http://dx.doi.org/10.1177/0143831X95163005

Schmid, G. (2006). Social risk management through transitional labour markets. Socio-Economic Review, 4, 1-33. http://dx.doi.org/10.1093/SER/mwj029

Schmid, G. (2007). Foreword. In B. Howe (Ed.), Weighing up Australian values (pp. 9-15). Sydney, NSW: New South Wales Press Ltd.

Schmid, G. (2011). Flexibility and security on the labour market: Managing and sharing parental risks. Journal of Economics and Social Policy, 14(1). Retrieved from http://epubs.scu.edu.au/jesp/vol14/iss1/5 
Schultz, V. (2000). Life's work. Columbia Law Review, 100(7), 1881-1891. http://dx.doi.org/10.2307/1123593

Scott, J., W. (1986). Gender: A useful category of historical analysis. The American Historical Review, 91(5, December), 1053-1075. Retrieved from http://links.jstor.org/sici?sici=0002-876\%28198612\%2991\%3A5\%3C1053\%3AGAUCOH\%3E2.0.CO\%3B $2-Z$

Shapiro, M., Ingolis, C., \& Blake-beard, S. (2007). Optioning in versus "opting out": Women using flexible work arrangements for career success. CGO Insights, 25. Retrieved from www.simmons.edu/som/docs/insights_25.pdf

Skills Australia. (2009). Foundations for the future. Proposals for future governance, architecture and market design of the national training system. Final position paper, June 2009. Canberra: Commonwealth of Australia.

Skills Australia. (2010). Australian workforce futures. A national workforce development strategy. Canberra: Commonwealth Australia.

Skills Australia. (2011). Skills for prosperity. A roadmap for vocational education and training. Canberra, Australia: Commonwealth of Australia.

Somekh, B., \& Lewin, C. (Eds.). (2005). Research methods in the social sciences. London: Sage Publications.

Stone, P. (2007). Opting out? Why women really quit careers and head home. Berkeley, CA: University of California Press.

Walter, M. (2005). Exploring mothers' relationship to the labour market. Just Policy, 35, 13-21.

Webber, G., \& Williams, C. (2008). Mothers in "good" and "bad" part-time jobs. Gender \& Society, 22(6), 752-777. http://dx.doi.org/10.1177/0891243208325698

Williams, J. (2000). Unbending gender. Why family and work conflict and what to do about it. New York: Oxford University Press.

Williams, J. C. (2003-2004). Beyond the glass ceiling: The maternal wall as a barrier to gender equality. Thomas Jefferson Law Review, 1, 1-14.

Williams, J. C. (2010). Reshaping the work-family debate. Why men and class matter. Cambridge, MA: Harvard University Press.

Yerkes, M., Standing, K., Wattis, L., \& Wain, S. (2010). The disconnection between policy practices and women's lived experiences: Combining work and life in the UK and the Netherlands. Community, Work and Family, 13(4, November), 411-427. http://dx.doi.org/10.1080/13668801003619407

Ziguras, S. (2006). Labour market transitions and risks of exclusion. Australian Bulletin of Labour, 32(3), 203 226.

\section{Authors}

Heather Fehring is currently an Associate Professor and is Deputy Head, Research and Innovation in the School of Education at the RMIT University. She has 30 years experience in education. Her career has spanned primary teaching, research, curriculum development and teaching in university settings. Dr. Fehring has been researching, presenting at conferences and publishing for many years in the areas of curriculum and Higher Education, children's literacy development specifically literacy development, critical literacy and literacy assessment and reporting. She won an Australian Research Council (ARC) grant in 2006 to research the area of graduate qualification and career trajectories. The work from this ARC project has informed this IES publication.

Katherine Herring (Graduate Diploma in Education and Bachelor of Arts (Honours) has been working as a research assistant within the School of Education, RMIT University for four years. Katherine's background is in education as she trained as a primary school teacher in the late 1990s. Katherine has a special interest in the Humanities and Women's issues. 